Немања Ј. Радуловић*

Универзитет у Београду

Филолошки факултет
УДК

821.134.2(83).09

929:341.7 Серано М.

ДОИ

https://doi.org/10.18485/analiff.2017.29.1.11

\title{
ДИПЛОМАТСКА МИСИЈА МИГЕЛА СЕРАНА У СФРЈ ${ }^{* *}$
}

\begin{abstract}
Чилеански писац Мигел Серано боравио је као амбасадор своје земље у Југославији 1962-1967. Овај део његове биографије представљамо на основу грађе архива Министарства инистраних послова и његових мемоара. С обзиром на природу грађе у центру су службени контакти, политичке активности (нарочито односи према блоковској политици, несврстанима), организовање посете Ј.Б.Тита,као и неке културне и економске размене, али и неколико проблема с аочигледно обавештајном позадином. Мемоари самог Серана дају личнији поглед, али и откривају и позадину неких збивања и оцену људи с којима се сретао (Тито, К. Поповић, Ранковић). Током боравка Серано није успоставио неки додир са домаћим књижевним круговима, али је контакт са Кочом Поповићем, тада министром спољних послова, превазишао чисто професионални. С обзиром на Серанов нацизам и интересовање за окултизам, занимљиве су и неке оцене које је југословенска страна имала о томе.
\end{abstract}

Кључне речи: дипломатија, југословенско-чилеански односи, несврстани, књижевност, неонацизам, окултизам

Мигел Серано Фернандес [Miguel Serrano Fernández] (19172009) био је чилеански књижевник, дипломата и езотериста. Пореклом из породице дипломата и писаца (ујак му је био угледни модернистички песник Висенте Уидобро), аутор је низа књига поетске, симболичне прозе инспирисаних различитим митологијама и источним учењима (No por mar, ni por tierra; Quién llama en los hielos; La serpiente del Paraiso; La flor inexistente; El/Ella. Libro del amor mágico;

*_nem_radulovic@yahoo.com

** У изради овог рада на различите начине помогли су: гђа Сабела Кинтела, удовица М. Серана; Дмитриј Борисович Зеленцов ; проф. Станко Црнобрња; запослени у Дипломатском архиву МИП-а и Историјском архиву Београда. Свима најсрдачније захваљујем. 
Nos, libro de la Resurección) које су се појавиле и у преводу на друге језике у време хиспаноамеричког бума, мада он није стекао славу Гарсије Маркеса или Кортасара. Српски читалац могао је да га упозна кроз књигу Херметиички круі, објављену први пут 1994. и једину засад преведену код нас, где говори о сусретима са Хесеом и Јунгом. Јунг, који није писао предговоре књижевним делима, учинио је једини изузетак за Серанову књигу Las visitas de la Reina de Saba. Поред Хесеа и Јунга, имао је прилике да упозна и Арнолда Тојнбија, Олдоса Хакслија, Езру Паунда, Јулијуса Еволу. У младости је био упознат са окултизмом и јогом, али и члан чилеанске национал-социјалистичке партије; касније је сретао фигуре светског неонацизма, укључујући и многе чувене нацисте из ратног периода (Леон Дегрел, Ото Скорцени). Овај део своје фигуре учинио је јавнијим када је објавио књигу El Cordón dorado: hitlerismo esotérico (1974) за којом су следиле Adolf Hitler, el último avatāra (1982) и Manú, por el hombre que vendrá (1991), те низ књига с краја 20. и почетка 21. в (Los ovnis de Hitler contra el nuevo orden mundial; Imitación de la Verdad; El hijo del viudo; Maya. La realidad es una ilusión). У овом делу свог опуса Серано излаже особену митологију тзв. езотеричног хитлеризма. У споју различитих космологија, суштински гностичком, централно место добио је Хитлер као десети аватар Вишнуа, који се бори против демијурга и његових роботских створења, првенствено Јевреја. Још 1947-1948. Серано је путовао на Антарктик као члан експедиције чилеанске морнарице, у вери да се тамо налази скривен Хитлер и његова база летећих тањира. Серано је последњих година живота био култна фигура у свету неонацизма; његова митологија утицала је на формирање езотеричних струја унутар овог покрета, али је имала одјека и у популарној култури и свету интернета (Више о овом аспекту његовог дела, као и о рецепцији у: Goodrick-Clarke, 2002: 173-192; Синер, 2012: 207-212; Strube, 2012; Strube, 2013: 156-159; Versluis, 2013; Strube, 2015).

За латиноамеричке писце, као и за српске, није било неуобичајено да служе у дипломатијама својих земаља, тако је и Серано, попут својих земљака Габријеле Мистрал и Пабла Неруде, велик део живота провео у чилеанској дипломатији. Био је амбасадор у Индији (1953-1961), којом је остао дубоко фасциниран, Југославији (19621967), истовремено акредитован (од 1965) у Румунији и Бугарској, Аустрији (1967-1971, са истовременом акредитацијом у Међународ- 
ној комисији за атомску енергију и у UNUDI, обе у Бечу) док га 1971. новоизабрани Аљенде није повукао, након чега се посветио писању. Дипломатија му је пружила прилику да упозна Нехруа, Индиру Ганди, Далај Ламу, с којима је развио односе ближе од формалних. У литератури се може срести податак да је Серано био амбасадор у Југославији 1962-1964. што није исправно. На амбасадорском положају био је све до 1967, међутим, од 1965. истовремено је акредитован и у Софији и Букурешту на нерезиденцијалној основи. Вероватно је податак о паралелним акредитацијама утицао да аутори помисле како је те године променио земљу.

У овом раду представићемо Серанов боравак у СФРЈ. ${ }^{1}$ Користимо грађу Дипломатског архива Министарства спољних послова, легат Коче Поповића и Лепе Перовић у Историјском архиву Београда, као и Серанову аутобиографију у четири тома. Најобимнији биобиблиографски преглед објавила је његова удовица Сабела Кинтела (2014, за југословенски период: 93-105), који овде такође користим. Нисмо имали могућност да користимо архиву чилеанског Министарства спољних послова, где се чувају његови извештаји из Београда. На основу оног што нам је било доступно, изгледа да додира са домаћим писцима готово да није било; нашли смо првенствено службене контакте. Ипак, и то је занимљиво за осветљавање боравка једног писца и контроверзне личности у нашој средини.

Серано је био први амбасадор Чилеа у Југославији. Дотад је ова земља имала само отправника послова и почасног конзула (а амбасадор у Бечу покривао је и Југославију). Очигледно је Чилеу било стало до подизања односа а Серано је изабран као особа од поверења за тај задатак. На основу грађе јасно је да амбасадорски положај за Серана није био нека синекура већ је у својим задацима био веома активан. Југословенска страна од почетка примећује да он жели да подигне ниво билатералних односа. У поверљивој белешци напомиње се да he ce ca Сераном моћи сарађивати много више него с претходником. ${ }^{2}$ Подсећам, период у ком Серано борави у СФРЈ време је формирања покрета несврстаних. Први самит одржан је у Београду 1961. са 25 чланова и три посматрача (већ на следећем у Каиру број чланова је

1 Користимо ово име, мада је у тренутку његовог доласка земља још увек носила назив ФНРЈ.

2 Оперативно писмо 12.11.1962 (ДА МСП-ПА 1962 ф. 17) 
готово удвостручен). Тито је био први генерални секретар (19611964). Такође, 1962. била је година кубанске кризе која је уздрмала хладноратовски свет, а посебно земље Јужне Америке. Настанак несврстаног покрета неопходан је контекст за разумевање Серанове активности. У Југославију је Серано упућен из друге несврстане земље, Индије, где је боравио дуго и остварио добре контакте са државним врхом. Када је поднета молба за агреман (9.01.1962.) Вељко Мићуновић у позитивном реферату (10.01.) $)^{3}$ истиче да је ово први пут да Чиле тражи агреман за амбасадора. Телеграм из Делхија истиче да Серано већ има нека познанства са домаћим људима као што је чилеански демохришћански сенатор хрватског порекла Радомир Томић, а познавао је и југословенске амбасадоре у Индији, Богдана Црнобрњу и Гојка Николиша. Одлучио је и да уместо дотадашњег стана тражи вилу ,јер има у стану цео музеј слика и уметничких предмета“. 4 Бродом из Индије, па возом из Ђенове, Серано је стигао у Београд у лето 1962. Сместио се у Молеровој 86, а Титу је акредитиве предао на Брионима 13. августа (Quintela 2014: 95).У једној белешци описан је као ,пријатељски и отворен човек, прилази с поверењем, али вероватно без конкретних планова“. планове. Након посете Коче Поповића земљама Латинске Америке, па и Чилеу (1962), Серано је сматрао да је време и за Титову посету и почео да ради на њеном остварењу. Домаћинима је такође истицао да је повезивање Чилеа са „неангажованим светом“ једина алтернатива за Латинску Америку. Према његовој оцени, Америка повећава притисак за изолацију Кубе, што доводи до јачања „конзервативних и реакционарних снага“, док СССР користи „нетактичност САД за самосталан продор“ тако да ниједна од суперсила „не утиче повољно на процес еманципације“. Титова посета би „ојачала курс независности и допринела афирмацији политике неангажованости у Латинској Америци“. 6 Забележено је 1964. да се интересовао за конференцију несврстаних и био активан по питању учешћа Чилеа у њој. ${ }^{7}$ (Сера-

3 Молба за агреман од 9.01.1962 (ДА МСП-ПА 1962 ф. 17)

4 Телеграм југословенске амбасаде из Делхија 13.04.1962. (ДА МСП-ПА 1962 ф. 17)

5 Разговори наших са страним представницима у ФНРЈ 10.08.1962 (ДА МСППА ф. 17).

6 Разговори наших са страним представницима у ФНРЈ (ДА МСП-ПА ф. 17).

7 Сусрет с Ј. Петрићем (2.03.1964) и Д. Солдатићем (6.04.1964) (ДА МСП-ПА 1964 ф. 29). 
нова процена спољнополитичких односа није нужно била одређена идеологијом, што значи да је пратио инструкције своје владе)

Очекивано, југословенска страна је повољно примила овакве изјаве о несврстанима, а очигледно је из неких изјава да Серано представља ствари онако како би се допале земљи домаћину, нпр. да југословенска штампа нетачно представља чилеанску владу као десну. Има ту и уско билатералних ствари: нпр. да ли ће Југославија подржати кандидатуру Чилеа у УНЕСКО. У разговору са В. Влаховићем ког је срео на вечери коју је приредио секретар америчке амбасаде (25.10.1962) рекао је да би Чиле подржао Кубу сличну Југославији. Забележено је да је говорио против инсталирања совјетских база, али и против интервенције: Куба треба да се ослони на Латинску Америку. Следеће године оцениће да је Куба изгубила на престижу јер се ослонила превише на једну страну, уместо да се на Латинску Америку. ${ }^{8}$ Са домаћинима је поделио и понешто од свог виђења источних односа: у индијско-кинеском сукобу (1962) држао је страну Индији сматрајући да је основни циљ Кинеза владавина Азијом. ${ }^{9}$ И касније је, у разговорима о вијетнамском рату, такође показао проиндијски став.“Не делује забринуто ако би САД бомбардовале нуклеарна постројења у Кини, чиме би се ова вратила неколико година уназад као велика сила“. ${ }^{10}$

Када је 1963. отишао у Чиле, у Југославију је дошла информација да је поднео позитиван извештај а Тита оценио као „великог државника међународне репутације, човека мира и мирољубиве сарадње“. Такође је истакао да има боље услове за рад него у Индији а да су људи отворенији. Серанов извештај о Куби је, по мишљењу југословенског МИП-а, утицао на став Чилеа у савету безбедности. ${ }^{11}$

Међутим, секретар амбасаде Стјепан Трампуж бележи и свој сусрет са Радомиром Томићем ком идеја о посети није била јасна.

8 Телеграм од 20.02.1963. (ДА МСП-ПА 1963 ф. 19).

9 Разговори наших са страним представницима у ФНРЈ (25.10.1962-ДА МСППА 1962 ф. 17). О индијско-кинеским односима и забелешка од 10.06 .1964 (на ручку у «Виноградима» који је Мома Марковић дао у част министра здравља Виљегаса) (ДА МСП-ПА 1964 ф. 29): «Кинези су успели да одстране Менона....Нехруа су убили...Сукоб с Кином га је сломио...Ипак, Кинези нису успели. Индија остаје неангажована. Према таквој политици се амбасадор, по свему судећи, односи са поштовањем и симпатијама».

10 Белешка о разговору (29.6.1966) (ДА МСП-ПА 1965 ф. 23)

11 Телеграм од 16.01.1963.(ДА МСП-ПА 1963 ф. 19). 
Према Томићу, влада је изразито конзервативна и није јој заиста стало до посете, а председник Алесандри блоковски оријентисан, тако да Чиле неће приступити политици неутралности. Ни спољна политика их не занима превише: Кубу подржавају само због личних трговачких интереса конзервативних велепоседника. Томић је напоменуо како је Серану рекао да добро промисли о посети, али да га овај није послушао. Југословенска страна је истовремено молила Серана да утиче да се спречи долазак Јурја Крњевића у Чиле, јер су имали информацију да ће агитовати против Титове посете. ${ }^{12}$

Серано је предао Титу лично писмо Алесандрија, као и званичан позив за посету, ${ }^{13}$ а разговарало се и о узвратној посети.У априлу је потврдио позив.Уједно су се, поводом писма удружења чилеанских писаца, Серано и Коча Поповић сложили да би у делегацији требало да буде и неко од југословенских писаца. (20.05.1963), тако да је ишао Блаже Конески.

Према новијим истраживањима, Чиле је био заинтересован за Титову посету још од 1959. али ово је код њега прошло без већег одјека јер је тада био усредсређен на Африку и Азију. Кубанска криза променила је ствари, тако да се Тито одлучио на пут због политичког приближавања јужноамеричких држава несврстанима и јачања сопствене позиције. Посета је реализована 17.09- 18.10. 1963. Посетио је Мексико, Боливију, Перу, Бразил, Чиле, а потом је продужио за САД где га је примио Кенеди. Сматра се да је овом турнејом Тито успео да оствари циљеве с којима је кренуо. Уједно је био први комунистички вођа који је посетио Латинску Америку (Ераковић 2015).

Серано је дакле радио на спровођењу идеје која је већ дуже постојала, али је изгледа требало сачекати подударање са интересима Југославије и лично Тита. Југословенски дипломатски извештаји о посети показују и понешто незадовољства. Пажње је вредно да је најаву посете подржала само левица, десница је очекивано била против, међутим центар и провладини медији били су уздржани и само донели обавештење, на изненађење амбасаде Југославије („Изненађује одсуство коментара провладине штампе“). ${ }^{14}$ Амбасада је протестовала

12 Забелешка о разговору (ДА МСП-ПА 1963 ф. 19)

13 Забелешка о азговору 6.03.1963 (ДА МСП-ПА 1963 ф. 19).

14 Извештај амбасаде из Чилеа 22.02.1963 (ДА МСП-ПА 1963 ф. 19). 
због „увредљивих израза“ у штампи (као што је диктатор). Серано у успоменама наводи да је Алесандри био за, да је било одређених отпора на левици и десници, али да је посета у принципу добила подршку. Такође помиње да је чилеанска страна била непријатно изненађена Титовим захтевима за високим нивоом обезбеђења, које му је одобрено (Serrano 1999: 83 ид.).

Тема која се више пута понавља јесте гранични спор Чилеа са Боливијом, око излаза на море; Серано је уложио енергије у заступање чилеанске тачке гледиште у СФРЈ. Ова регионална тема нас заправо одводи ка преиспитивању неких званично забележених изјава у архивској грађи. У мемоарима Серано објашњава да о несврстанима није имао превише илузија. Ценио је Нехруа и његову амбицију да постане светски лидер у чему је, по Серановој оцени, и успео увевши Индију међу кључне земље света. Сами несврстани, како каже „нису били неутрални, већ су хтели да остану активни у својој маргиналности“ (Serrano, 1998: 115). То што Југославија није подржала Индију у рату са Кином, за Серана је био знак слабих основа покрета (Serrano, 1998: 222). Међутим, када је Тито најавио посету Северној и Јужној Америци, за коју је била планирана и Боливија, учинило му се важним да посети и Чиле, да би се спречило прихватање боливијске тачке гледишта у граничном спору. Документи из МИП-а показују да је чак инсистирао да Тито посети што мањи број земаља да би посета добила на значају. Из накнадне перспективе, ангажман око посете протумачио је искључиво интересима земље у односу с Боливијом, не блоковском политиком.

Када је 1964. нови председник постао Едуардо Фреј, ког је познавао лично, предлагао је Б. Црнобрњи организацију посете Југославији, претпостављајући да ће „водити политику блиску несврстанима““. ${ }^{15}$ Очекивало се да ће Серано напустити дужност 1965: већ је био одређен и нови амбасадор, ком је југословенска страна дала агреман, али је због унутрашњих политичких разлога чилеанска власт одустала и одлучила да Серано остане. Серано је форсирао посету Фреја, али је овај одустао, на незадовољство југословенског МСП-а. ${ }^{16}$

У оквиру своје мисије Серано је такође је постигао и важан економски споразум; долазиле су и привредне (1963), синдикалне (1963)

15 Забелешка о разговору 10.02. и 13.02. (ДА МСП-ПА 1964 ф. 29)

16 ДА МСП-ПА 1964 ф. 29 
и парламентарне (1965) делегације (у једној је био и С. Аљенде, 1966). Ширење нуклеарног оружја неибежно је морала бити тема тог периода. Серано захваљује што је у коминикеу Тито-Насер дата подршка безатомској зони у Латинској Америци, а 1963. на подршци дезатомизацији писмом је Титу захвалио и Алесандри. „У поверењу“ је саопштио ДСИП-у и да тајно путује у Источну Немачку због успостављања трговачких односа, где је добро примљен. ${ }^{17}$ Распитивао се за могућност да Чиле купи од Југославије лако пешадијско наоружање и патролне чамце, због могућег сукоба с Аргентином. Добио је начелно позитиван одговор, али му је затражено да упути конкретан захтев, до чега изгледа није дошло. ${ }^{18}$ У његовом другом мандату односи са домаћинима донекле су се заоштрили. Серано је био веома активан у склапању уговора којим би Југославија куповала бакар од Чилеа. Ту је дошло до неспоразума и размимоилажења, а нека званично поднета мишљења оптужују Серана да се умешао да би добио високу провизију. ${ }^{19}$

На културном плану треба поменути организовану изложбу фресака у Чилеу, као и посету фолклорног ансамбла „Лада“. Двојица чланова тражила су азил током гостовања у Чилеу; Серано саопштава да ће захтев бити одбијен, али моли да се с тим не излази у јавност ${ }^{20}$ (било би интересантно знати шта је с њима било после). Чилеански ансамбл који је водила суприга чилеанског министра спољних послова гостовао је на Дубровачким летњим играма. Југославију је посетио писац Фернандо Гонсалес Урисар, док је разматрана узвратна посета Оскара Давича. ${ }^{21}$

Требало је и да у Југославију 1966. дође познати песник Хувенсио Ваље а Серано је обезбедио четвромесечну стипендију за уметника Хулија Ескамеса Караска. ${ }^{22}$ Ескамес је аутор цртежа цвета који је Серано користио као знак на својим књигама (Quintela 2014: 85). Чиле je 1962. требало да посети хрватски песник Никола Милићевић. ${ }^{23}$ Кад је о литерарним везама реч, поменимо да је приликом међународног

17 Забелешка о разговору (10.02.1965) (ДА МСП-ПА 1965 ф. 23).

18 Забелешка о разговору 25.11.1965 (ДА МСП-ПА 1965 ф. 23)

19 ДА МСП-ПА 1966 ф. 26

20 ДА МСП-ПА 1962 ф. 17

21 ДА МСП-ПА 1963 ф. 19

22 Амбасада СФРЈ у Софији (12.12.1966) ДА МСП-ПА 1966 ф. 25; Амбасада СФРЈ у Сантјагу (28.01.1966)ДА МСП-ПА 1966 ф. 26

23 http://163.247.50.16/webrree.nsf/vwFondoPaises/541C0D67255998E084257984 005353A8?OpenDocument 
скупа писаца имао прилике да званично дочека Неруду, кога је раније на сличан начин примио и у Индији (мада га иначе није ценио ни као песника ни као, очекивано, политичара). И Неруду и М. А. Астуријаса возио је по унутрашњости Југославије да им покаже пејзаже. (Serrano, 1997:51). Постојала је и универзитетска сарадња; давале су се стипендије за студенте и постдипломце у оба правца (носиоци југословенских били су, поред других, и син и зет председника Фреја).

Но поред размена комплимената, југословенска страна је знала да чилеански амбасадор мисли и другачије. Секретар југословенске амбасаде у Сантјагу С. Трампуж извештава о сусрету са двојицом чилеанских комуниста који су Серана знали приватно. Један је Волођа Теителбојм Волоски, други Сесар Годој Урутија. Теителбојм (1916-2008) је био писац руско-јеврејског порекла, активан комуниста. Са Сераном се знао од младости. „Много говорили о Серану, садашњем њиховом Амбасадору у Београду. Потврђују оно што смо већ знали, да био раније нациста и да био директор неких нацистичких или про-нацистичких новина. Касније се предао мистици. Под јаком импресијом далајиламе. Бавио се вјештином yoga. Уколико стекне добру импресију о Југославији, а на то могу да утичу вањске импресије и мистицизам, онда може да нам буде од користи. У обратном случају, може да нам много штети“. ${ }^{24}$

У Београду је, приликом састављања листе за одликовања приликом посете Чилеу, одлучено да Тито Теителбому уручи Орден југословенске заставе са златним венцем. ${ }^{25}$ Такође је у својству сенатора посетио Југославију (приликом састанка са Вељком Влаховићем стигао је и да расправи проблеме соцреализма у књижевности), а том га је приликом Серано угостио. Серано помиње да је Теителбома допратио важан песник, члан Централног комитета, Јеврејин - мада Серано не помиње име, то очигледно мора бити Давичо (Serrano, 1999: 18). ${ }^{26}$

Ако југословенска страна није до краја веровала Серану, исто тако ни он није имао лепо мишљење о режиму у ком се налази, али који је одвајао од становништва. У својим успоменама он саопштава да о дипломатској служби неће говорити, али за Југославију пра-

24 Забелешка -разговор (ДА МСП - ПА 1963 ф. 19).

25 За одликовања од 31.08.1963. ДА МСП - ПА 1963 ф. 19.

26 Теителбојм је описан као «један од најистакнутијих чилеанских комуниста»; од свих чланова Централног комитета «наши односи с њим су били најразвијенији» (Чиле-информација од 20.11.1965 - ДА МСП-ПА 1965 ф. 23) 
ви изузетак и посвећује том периоду доста простора (Serrano, 1999: 71-113). Неизбежно личнији од архивске грађе, писани са временске дистанце и поуздани онолико колико су то иначе сећања дипломата и политичара, ови су мемоари занимљиви како због неких политичких коментара на окружење у ком је био, тако и због поетског односа према природи земље.

Како Серано ретроспективно каже, по завршетку свог мандата у Индији није био расположен за одлазак у комунистичку земљу Источне Европе, већ је тражио Кубу као ближу кући. Међутим, Џон Галбрајт (економиста, амерички амбасадор у Индији 1961-1963) саветовао му је да оде у Југославију као у једну од тренутно кључних земаља за САД, заједно са Индијом. Као доказ тога навео је да је Џорџ Кенан пре службе у СССР био у Југославији (Serrano, 1998: 219; Serrano 1999: 83).

Знајући у какво друштво иде, Серано је добро обратио пажњу неколико практичних савета које је добио од колега (да мења кључеве сваких пола године, да током разговара удара оловком по столу да би ометао снимање исл.) За домаћу послугу знао је да обавештајним службама подноси недељни извештај о његовим активностима.

Интересантно је у том погледу поменути и мању аферу са доларским новчаницама којима је платио авио карту, а за које се испоставило да су биле фалсификоване. Његово објашњење било је да је афера намештена као освета обавештајне службе за предлог чилеанском министарству да амбасаду премести у Атину; међутим, када су схватили да у Чилеу предлаже посету Тита, ликвидирали су аферу. Документа из МИП-а показују само протоколарни извештај, према коме је Серано дао фалсификоване доларе ${ }^{27}$ ако је било обавештајне позадине, онда се њена потврда налази у неким још неприступачним архивима.

И према архивској грађи знамо да се неколико пута жалио у ДСИП-у да му се отвара пошта, али без подношења званичне жалбе. Саопштено му је да се „с обзиром на наше уставне гаранције искључује одговорност југословенске стране“. „Амбасадор Серано у пар наврата и неформално постављао је и раније питање контролисања и нестајања његових писама (начелнику, помоћнику и референту у овој

27 Сусрет са Ј. Петрићем 6.03.1963. и М. Никезићем 7.03.1963. (ДА МСП 1963 ф. 19) 
Управи. Тим поводом начелник и помоћник III Управе водили су разговоре са начелником једног одељења у Државној безбедности СФРЈ, који је након провере обавестио да није установио никакве неправилности на пошти, па према томе и закључио да се писма отварају или нестају пре уласка у Југославију“. ${ }^{28}$ Очигледно је, попут ДБ-а, и пошта била забринута за уставне гаранције, па је ПТТ је одредио посебног службеника да пази на поштански преградак амбасаде. Г.1965 Серано је протестовао што су службеници протокола улазили у стан док је он био одсутан, званично да би га показали сиријском амбасадору. ${ }^{29}$

Смену Ранковића, која се десила у време његовог мандата, оценио је као сукоб британске и совјетске обавештајне службе у којој је Ранковић као совјетски човек пао (напомињем још једном да се ова процена даје према мемоарима; извештај из тог периода мора се налазити у Сантјагу). Тита је директно назвао британским агентом. Када је на Брионима информисан да ће Коча Поповић наследити Ранковића, отишао је за Трст да одатле пошаље писмо Фреју (очигледно да би избегао шпијунирање дипломатске поште). Неке од његових судова из каснијег периода, када пише мемоаре, треба читати опрезно, јер често нису дипломатска анализа већ део тезе о светским заверама (Serrano, 1998: 252ид.).

Серанов боравак у Индији и лично познанство са Индиром Ганди (били су на ти) допринели су већој блискости са југословенским врхом. Када је Нехру умро, југословенска делегација га је примила у свој авион којим су ишли на сахрану. Приликом њене посете 1966, био је на Брионима и са совјетским амбасадором и Кочом Поповићем, али су на вечери били без амбасадора СССР. У приватном разговору Индира Ганди, која је сутрадан требало да иде у СССР због сусрета са Брежњевим, ког није знала, питала га је за мишљење о новом совјетском вођи, али јој је Серано препоручио да се информише више код Тита. По повратку из СССР у Југославију она је и поред густог распореда нашла времена за сусрет са Сераном који јој је показивао Београд (Serrano, 1998: 252 ид.).

28 Забелешка (29.06.1966); писмо ДСИП-а ПТТ-у (2.08.1966); одговор ССУП-а ДСИП-у (8.10.1966); извештај од 14.10.1966; допис ПТТ-а ДСИП-у од 19.09.1966 (све у:ДА МСП-ПА 1966 ф. 25).

29 Забелешка од 4.01.1965 ДА МСП-ПА 1965 ф.23 
Према Титу је имао амбивалентан однос. Није му био нимало симпатичан (,хладно плаве очи, без сјаја, а лице му је остајало безизражајно“ - Serrano, 1999: 75), али признаје личну љубазност која се посебно испољила приликом посете Чилеу (због интерних сплетки своје стране Серано је изостављен са свечане вечере, али је интервенцијом југословенске делегације враћен-Коча Поповић му је уступио своје место). Разне приче које су колале о Титу допрле су и до њега: да је агент или да је за време рата узео идентитет правог Јосипа Броза. Сматрао је и да Де Гол не жели контакт са њим због погубљења Драже Михаиловића. Пратио је Тита у посети Румунији 17.04.1966 (Quintela, 2014: 104)

Још у Индији успоставио је блиски контакт са амбасадором Црнобрњом, ког је после сретао и у Југославији. Према саопштењу Станка Црнобрње, југословенски дипломата је, као и Серано, био примљен у ужи круг Нехруа, у који овај иначе дипломате није пуштао, тако да су ту могли да се зближе, тим пре јер се Црнобрња у Индији заинтересовао за источне филозофије и религије

И контакт са Кочом Поповићем (министар спољних послова 1953-1965, потпредседник Југославије 1966-67) превазишао је чисто професионални. Серано отворено пише да је имао и према њему амбивалентан однос: колико га је одбијала комунистичка идеологија, толико је ценио оно што је видео као личне квалитете. У мемоарима је објавио и два писма (Поповићево њему 3.11.1964. и његов одговор 5.11.1964- Serrano, 1999: 94-95), из којих видимо да су дискутовали о материји и антиматерији и о гладнима у свету (што Серано преводи на метафизички ниво). ${ }^{30}$ Поповић се чуди Серановој тврдњи да је Кафка посетио Девин (познатији по Рилкеу). Сераново писмо писано је, како објашњава, на непалској хартији, коју користи само за посебне прилике: писати на њој подсећа га на књигу Јуйро чаробњака. ${ }^{31}$ Уз Феномен човека Тејара де Шардена шаље Поповићу и своју књигу Посеие краљище og Сабе. „Написао сам је у Индији, у соларном добу,

30 Оригинал Серановог писма чува се у Легату Коче Поповића и Лепе Перовић у Историјском архиву Београда (кутија 34); 4 стране, на шпанском; у опису фонда није идентификован пошиљалац. У књизи га преноси машинописно, док је изворник рукопис.

31 Књига Повелса и Бержијеа која је тад изашла и ужживала велику популарност; својим тезама о езотеричној страни нацизма утицаће на Серана. 
покушавајући да пливам - да „пецам“ - у дубоким морима древних митова и легенди. То је уистину опасна игра са сенком коју баца љубав, како сте објаснили овог лета мом сину на златним обалама ваше лепе Далмације“ (исто). Поред ове, поклонио му је с посветом и књи-

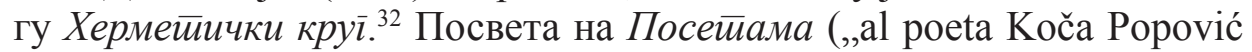
en amistad“) даје се као успомена на „на ноћно путовање у стару луку Валпараиса“" (8. мај 1967). У једном тексту из 1990. Серано помиње како му је Поповић приликом посете 1963. тражио да му покаже ноћни живот ове луке, јер се мало странаца тиме може похвалити (Serrano 1990). Посвета у Хермейичком круїу знатно је краћа и формалнија, уз визиткарту с нотицом и поздравима.

(Човек не може да а не замишља разговоре шпанског борца и езотеричног хитлеристе. И на крају, каква би била дипломатија без анегдота: када је Серану Коча Поповић вратима аутомобила повредио руку, медицинску интервенцију указала је Јованка Броз, због чега су Серана прогласили партизаном.....)

Почетком 1967. одређен је нови амбасадор, Даниел Барио, ком је Тито дао агреман. Серано је на пролеће испраћен уз уобичајене протоколарне свечаности: опроштајни ручак и предлог Марка Никезића Генералном секретаријату председништва да се одликује Орденом југословенске заставе са лентом. ${ }^{33}$ На растанку је Титу поклонио једну Ескамесову слику. У Београду је боравио до краја маја, али га је 12.10. исте године у Белом двору примила Индира Ганди (Quintela, 2014:110).

Боравак у Београду је за Серана био плодан. Тада је написао више чланака (поводом смрти Хесеа и Нехруа; о Јунгу, Далај лами, Рилкеу и Тејару де Шардену, летећим тањирима, „граду голема“, маји итд), углавном за чилеанске листове. Објавио је књиге Рајска змија (1963, шпански и енглески) и Херметиички круі (1965; енглески превод 1966). Завршио је 1964. и Нейостиојећи извей (објављен 1969). Нешто интимнији доживљај налазимо на страницама мемоара које откривају фасцинацију „београдским шумама“, где је водио и Индиру Ганди, нарочито један посебан мистичан, симболичан однос према дрвету које је изабрао за своје ( "mi Árbol amigo “)-ту видимо песника и мистика.

32 Обе се такође чувају у легату (издања: Las visitas de la reina de Saba, Nascimento, Nueva Delhi, 1969; El circulo hermetico. De Hesse a Jung, Zig-Zag, Santiago de Chile, 1965).

33 Генералном секретаријату Председника Р епублике (17.04.1967); Белешка о Чилеу (4.05.1967) (ДА МСП-ПА 1967 ф. 24). 
Општи утисак, који је остао и неколико деценија после, јесте „туга земље и лепота људи“. „...Ванредан народ, раса, лепоте без премца у мушкараца и жена, неупоредивих јуначких и ратничких квалитета, и с нежном љубављу за своју земљу. И ово код Срба као и код Хрвата, код Црногораца као и код Босанаца“"(Serrano 1999: 71). 1991. је објавио два текста о југословенској кризи у дневном листу Меркурио. У успоменама помиње и да је задржао контакт са једном српском чланицом медицинског особља које је комуницирало са дипломатама (њен портрет је урадио Ескамес) и помогао јој да напусти земљу и дође у Чиле током напада на Србију 1999.

Како видимо, Серано је био веома ангажован у спровођењу политике владе која је изгледа одлучила да испита политику несврстаних. Мада је постојала и културна размена, до Серановог контакта са српским писцима изгледа да није дошло. И поред његовог интересовања за езотеризам, још је мање вероватно да је могао имати неке контакте са домаћим езотеричним миљеом. Овај се почетком шездесетих година, колико нам је познато, састојао махом од старијих, предратних београдских теозофа и антропозофа који су се налазили приватно, по становима (Милош Радојчић, Ксенија Атанасијевић). Чак и да је био заинтересован, није било за очекивати да је страни дипломата у условима свеопштег ухођења и диктатуре могао лако да успостави контакт са овим круговима.

\section{Библиографија}

Goodrick-Clarke, N. (2002). Black Sun. Aryan Cults, Esoteric Nazism and the Politics of Identity. New York and London: New York University Press.

Quintela, S.P (2014). Miguel Serrano. BioBibliografia. Santiago: EB Libros.

Strube, J. (2012). Die Erfindung des esoterischen Nationalsozialismus im Zeichen der Schwarzen Sonne. Zeitschrift für Religionswissenschaft,20, 223-268.

Strube J. (2013). Vril. Eine okkulte Urkraft in Theosophie und Esoterischem Neonazismus. München: Wilhelm Fink Verlag.

Strube, J. (2015). Nazism and the Occult. In Ch.Partridge (ed.) The Occult World (pp. 336-347). Oxon-New York: Routledge.

Versluis, A. (2013). Savitri Devi, Miguel Serrano and the global phenomenon of esoteric Hitlerism. In H. Bogdan\&G. Djurdjević (eds.), Occultism in Global Perspective (pp.121-133). Durham: Acumen. 
Ераковић, В. (2015). Титова „америчка турнеја“ 1963. године - посета Бразилу, Чилеу, Боливији, Перуу и Сједињеним Америчким Државама. Архив: часойис Архива Јуїославије 16, 168-179.

Синер, Р. (2011). Срно сунце. Уйойреба и злоуйойреба мийова у националсоиијализму и яесничарској езоиеерији. Београд: Златни змај.

\section{Извори}

SERRANO, M. (1990). En los grandes tiempos, desde Valparaíso nos proyectábamos al mundo. EL MERCURIO (Santiago de Chile), 13 de febrero de 1990. Доступно преко: http://www.miguelserrano.cl/site/valparaiso [6.05.2017]

Serrano, M (1996) Memorias de Él y yo. 1. Chile: Ediciones Mar del Plata.

- (1997) Memorias de Él y yo. 2. Chile: Ediciones Mar del Plata.

- (1998) Memorias de Él y yo. 3. Chile: Ediciones Mar del Plata.

- (1999) Memorias de Él y yo. 4. Chile: Ediciones Mar del Plata. архивска грађа

ДА МСП-ПА. Дипломатски архив Министарства спољних пословаПолитички архив.

- ПА 1962 Чиле 17

- ПА 1963 Чиле 19

- ПА 1964 Чиле 29

- ПА 1965 Чиле 23

- ПА 1966 Чиле 25

- ПА 1966 Чиле 26

- ПА 1967 Чиле 24

ИАБ-ЛКП - Историјски архив Београда-Легат Коче Поповића и Лепе Перовић 
Nemanja Radulović

\section{Summary}

\section{MIGUEL SERRANO 'S DIPLOMATIC MISSION IN YUGOSLAVIA}

Miguel Serrano Fernández (1917-2009) was a Chilean writer, diplomat and esotericist. The paper presents his service in Yugoslavia 1962-1967, period when he published couple of books, including famous Hermetic Circle. Sources we use are materials from the archive of Serbian Ministry of foreign affairs and Serrano 's memoires. Documents show that Chile in that period was interested in the new movement of non-aligned countries, so Serrano was transferred from one founding country of the movement (India) to another (Yugoslavia). Following instructions, he was very active in organizing Tito 's visit to Chile in 1963. His contacts wee mostly official, although he established closer relations with Koča Popović, minister of foreign affairs and surrealist poet himself. Some problems Serrano encountered most probably had background in intelligence activities, as Yugoslavian side was aware of his pro-Nazi and occult inclinations.

Key words: diplomacy, Yugoslav - Chilean relations, literature, nonaligned, neo-nazism, occultism 